\title{
LEGIBILITY
}

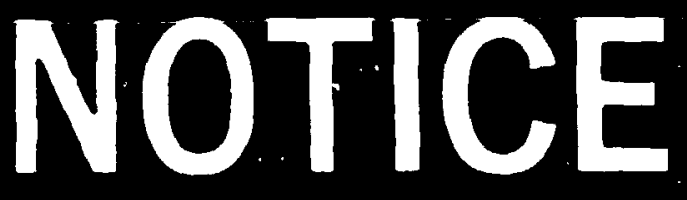

A major purpose of the Technical Information Center is to provide the broadest dissemination possible of information contained in DOE's Research and Development Reports to business, industry, the academic community, and federal, state and local governments.

Although a small portion of this report is not reproducible, it is being made available to expedite the availability of information on the research discussed herein. 


\title{
HEALTH AND SAFETY RESEARCH DIVISION
}

Waste Management Research and Development Programs

(Activity No. AH 100500 0, NEAHOD1)

\section{RESULTS OF THE RADIOLOGCAL SURVEY AT \\ 146 W. CENTRAL AVENUE, MAYWOOD, NEW JERSEY (MOBA)}

\author{
R. D. Foley and R. F. Carrier
}

Date Published - November 1989

\section{Investigation Team}

R. E Swaja - Measuremen Applications and Development Manager

W. D. Cottrell - FUSRAP Projec: Director

R. D. Foley - Field Survey Supervisor

Survey Team Members
A. C. Butler"
R. A. Mathis
J. L Quillent
P. F. Tiner
M. E Ward*
W. Winton

-D. R. Stone Associates, Inc. tNuclear Fuel Services, linc.

Work performed by the MEASUREMENT APPLICATIONS AND DEVELOPMENT GROUP

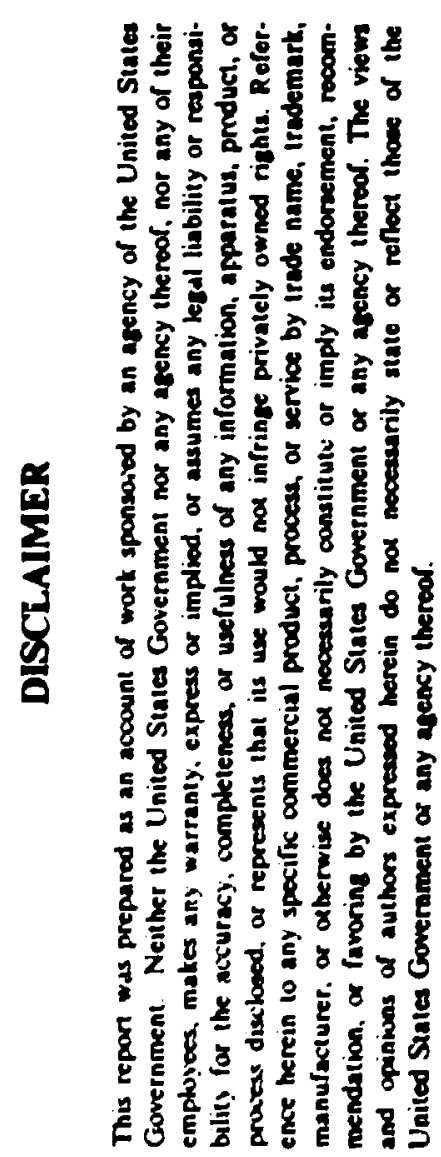




\section{CONTENTS}

LIST OF FIUURES $\ldots \ldots \ldots \ldots \ldots \ldots \ldots \ldots \ldots \ldots$

LIST OF TABLES $\ldots \ldots \ldots \ldots \ldots \ldots \ldots \ldots \ldots \ldots$ vii

ACKNOWLEDGEMENTS $\ldots \ldots \ldots \ldots \ldots \ldots \ldots \ldots$ ix

ABSTRACT $\ldots \ldots \ldots \ldots \ldots \ldots \ldots \ldots \ldots \ldots \ldots \ldots \ldots$

INTRODUCTION $\ldots \ldots \ldots \ldots \ldots \ldots \ldots \ldots \ldots \ldots$

SURVEY METHODS $\ldots \ldots \ldots \ldots \ldots \ldots \ldots \ldots \ldots$

SURVEY RESULTS $\ldots \ldots \ldots \ldots \ldots \ldots \ldots \ldots \ldots$

Indoor Survey Results . . . . . . . . . . . . . . 3

Surface Gamma Radiation Levels . . . . . . . . . . 3

Airborne Radon Concentrations ............... 3

Outdoor Survey Results . . . . . . . . . . . . . 3

Gamma Radiation Levels . ................. 3

Systematic and Biased Soil Samples .............. 4

Auger Hole Soil Samples and Gamma Logging .......... 4

SIGNIFICANCE OF FINDINGS $\ldots \ldots \ldots \ldots \ldots \ldots \ldots$

REFERENCES $\ldots \ldots \ldots \ldots \ldots \ldots \ldots \ldots \ldots \ldots \ldots \ldots \ldots \ldots \ldots \ldots$ 


\section{LST OF FIGURES}

1 Gamma radiation levels $(\mu \mathrm{R} / \mathrm{h})$ measured on the surface at 146 West Central Avenue, Maywood, New Jersey (MJ034) . . . . 7

2 Diagram showing locations of soil samples taken at 146 West Central Avenue, Maywood, New Jersey (MJ034) . . . . 8

3 Gamma profile of auger hole 1 at 146 West Central Avenue, Maywood, New Jersey . . . . . . . . . . . . . . . . . 9

4 Gamma profile of auger hole 2 at 146 West Central Avenue, Maywood, New Jersey . . . . . . . . . . . . . . 10

5 Gamma profile of auger hole 3 at 146 West Central Avenue, Maywood, New Jersey . . . . . . . . . . . . . . . . 11

6 Gamma profile of auger hole 4 at 146 West Central Avenue, Maywood, New Jersey . . . . . . . . . . . . . 12 


\section{LIST OF TABLES}

1 Applicable guidelines for protection agzinst I jiation $\ldots \ldots \ldots \ldots 13$

2 Background radiation levels for the northern New Jersey area $\ldots . .14$

3 Concentrations of radionuclides in soil at 146 West Central Avenue, Maywood, New Jersey (MJ034) . . . . . . . . . 15 


\section{ACKNOWLEDGMENTS}

The Division of Facility and Site Decommissioning Projects, U. S. Department of Energy, sponsored the research for this project under contract DE-AC05-84OR21400 with Martin Marietta Energy Systems, Inc. The authors wish to acknowledge the support of J. E. Baublitz Acting Director, Office of Remedial Action and Waste Technology, J. J. Fiore, Director, Division of Facility and Site Decommissioning Projects; and members of their staffs. The authors also appreciate the contributions of the following members of the Health and Safety Research Division for their participation in the collection, analyses, and reporting of data for this survey: B. S. Ellis (former employee) R. A. Mathis, D. A. Roberts, P. F. Tiner, W. Winton, and T. R. Stewart of the Measurement Applications and Development Group. Thanks are also extended to A. C. Butler and M. E. Ward of D. R. Stone Associates, Incorporated, and J. L Quillen, Nuclear Fuei Services, Inc. 


\begin{abstract}
Maywood Chemical Works (MCW) of Maywood. New Jersey, generated process wastes and residues associated with the production and refining of thorium and thorium compounds from monazite ores from 1916 to 1956 . MCW supplied rare earth metals and thorium compounds to the Atomic Energy Commission and various other government agencies from the late 1940s to the mid-1950s. Area residents used the sandlike waste from this thorium extraction process mixed with tea and cocoa keaves as mulch in their yards. Some of these contaminated wastes were also eroded from the site into Lodi Brook At the request of the U.S. Department of Energy (DOE), a group from Oak Ridge National Laboratory conducts investigative radiological surveys of properties in the vicinity of MCW to determine whether a property is contaminated with radioactive residues, principally ${ }^{232} \mathrm{Th}$, derived from the MCW site. These surveys typically include direct measurement of gamma radiation levets and soil sampling for radionuclide analyses. The survey of this site, a private property at 146 West Central Avenue. Maywood New Jersey (MJ034), was conducted during 1987 and 1988
\end{abstract}

While some measurements at at this property were greater than background levels typically encountered in the New Jersey area, no radiation levels nor radionuclide concentrations exceeded the guidelines established by the DOE for the Maywood, New Jersey, area remedial action plan. However, because of the proximity of the railroad property, which will be remediated, and the DOE's ALARA (As Low As Reasonably Achievable) policy, concurrent removal of the slightly elevated soil layers at $146 \mathrm{~W}$. Central Avenue may be justified. 


\section{RESULTS OF THE RADIOLOGICAL SURVEY AT 146 WEST CENIRAL AVENUE, MAYWOOD, NEW JERSEY (MJ034)*}

\section{INTRODUCTION}

From 1916 to 1956, process wastes and residues associated with the production and refining of thorium and thorium compounds from monazite ores were generateci by the Maywood Chemical Works (MCW), Maywood, New Jersey. During the latter part of this period. MCW supplied rare earth metals and thorium compounds to various government agencies. In the 1940 s and 1950 s. MCW produced thorium and lithium, under contract. for the Atomic Energy Commission (AEC). These activities ceased in 1956, and approximately three years later, the 30-acre real estate was purchased by the Stepan Company. The property is located at 100 Hunter Avenue in a highly developed area in Maywood and Rochelle Park, Berges County, New Jersey.

During the earty years of operation. MCW stored wastes and residues in Inw-lying areas west of the processing facilities. In the early 1930s, these areas were separated from the rest of the property by the construction of New Jersey State Highway 17. The Stepan property, the interim sturage facility, and several vicinity properties have been designated for remedial action by the Department of Energy (DOE).

The waste produced by the thorium extraction process was a sandlike material containing residual amounts of thorium and its decay products, with smaller quantities of uranium and its decay products. During the years 1928 and 1944 to 1946, area residents used these process wastes mixed with tea and cocoa leaves as mulch in their lawns and gardens. In acdition. some of the contaminated wastes were apparently eroded from the site into Lodi Brook and carried downstream.

Lodi Brook is a small stream flowing south from Maywood with its headwaters near the Stepan waste storage site. Approximately $150 \mathrm{ft}$ after passing under State Route 17. the stream has been diverted underground through concrete or steel culverts urtil it merges with the Saddle River in Lodi. New Jersey. Only a small section near Interstate 80 remains uncovered. From the 19403 to the 1970 s when the steam was being diverted underground, its course was altered several times. Some of these changes resulted in the movement of contaminated soil to the surface of a few properties, where it is still in evidence. In other instances, the contaminated soil was covered over or mixed with clean fill, leaving no

- The survey was performed by members of the Measurement Applications and Development group of the Health and Safety Research Division at Oak Ridge National Laboratory under U. S. DOE contract DE-ACO5-84OR21 tMo with Martin Marietta Energy Systems, Inc. 
immediate evidence on the surface. Therefore properties in question may be drilled in search of former stream bed material. even in the absence of surface contamination.

As a result of the Energy and Water Appropriations Act of Fiscal Year 1984, the property discussed in this report and properties in its vicinity contaminated with residues from the former MCW, were included as a decontamination research and development project under the DOE Formerty Utilized Sites Remedial Action Program. As part of this projech. DOE is conducting radiological surveys in the vicinity of the site to identify properties contaminated with residues derived from the MCW. The principal radionuclide of concern is thorium-232. The radiological survey discussed in this report is part of that effort and was conducted, at the request of DOE, by members of the Measurement Applications and Development Group of the Oak Ridge National Laboratory.

A radiological survey of the private, residential property at 146 West Central Avenue, Maywood, New Jersey, was conducted on August 26 and 27, 1987. Additional subsurface investigations were performed in June 1988. The New York Susquehanna and Western Railway line abuts the south end of the property. The interim storage facility is immediately adjacent to the far side of the tracks.

\section{SURVEY METHODS}

The radiclogical survey included: (1) a gamma scan at the surface of the entire property outdoors; (2) gamma exfosure rate measurements at $1 \mathrm{~m}$ above the surface indoors; (3) collection of surface and subsurface soil samples; (4) gamma profiles of auger holes; and (5) the determination of indoor radon and radon progeny concentrations. The survey methods followert the plan outlined in Reference 1. A comprehensive description of the survey methods and instrumentation has been presented in another report ${ }^{2}$

Using a portable gamma scintillation meter, ranges of measurements were recorded at $1 \mathrm{~m}$ above the surface in each room of the house. In areas of elevated exposure rates, airborne radon and radon progeny concrntrations were determined by filtration and subsequent alpha spectriometric analysis of air samples.

Gamma exposuri rates were also recorded for areas of the property surface outdoors. Systematic soil samples were then obtained at randomly selected locations irrespective of gamma exposure rates. In addition, biased soil samples were collected in areas of elevated gamma levels. To define the extent of possible subsurface soil contamination, auger holes were drilled to depths of approximately $2.7 \mathrm{~m}$. A plastic pipe was placed in each hole, and a NaI scintillation probe was lowered inside the pipe. The probe was encased in a lead shield with a horizontal row ci collimating slits on the side. This collimation allows measurement of gamma radiation intensitics resulting from contamination within small fractions of the hole depth. Measurements were made at 15-. 
$20-$ or $30-\mathrm{cm}$ intervals. If the gamma readings in the hole were elevated, a soil sample was scraped from the wall of the auger hole at the point showing the highest gamma radiation level. The auger hole loggings were used to select locations where further soil sampling would be useful. A split-spoon sampler was used to collect subsurface samples at known depths. In some auger holes, a combination of split-spoon sampling and side-wall scraping was used to collect samples.

\section{SURVEY RESULTS}

Applicable federal guidelines are summarized in Table $10^{3}$ The normal background radiation levels for the northern New Jersey area are presented in Table 2. These data are provided for comparison with survey results presented in this section. All direct measurement results presented in this report are gross readings; background radiation levels have not been subtracted. Similarly, background concentrations have not been : abtra_ted from radionuclide concentrations measured in environmental samples.

\section{Indoor Survey Results}

\section{Gamma Radiation Levels}

Gamma radiation levels at $1 \mathrm{~m}$ abov - the floor surfaces :vere 9 to $11 \mu \mathrm{R} / \mathrm{h}$ in most of the rooms in the house. Exposure rates above the typical background average of $8 \mu R / h$ (Table 2) were measured in both ends of the basement (10 to $17 \mu \mathrm{R} / \mathrm{h}$ ), and in the ground Ar,or den (9 to $15 \mu \mathrm{R} / \mathrm{h}$ ). All values are below the DOE guideline of $20 \mu \mathrm{R} / \mathrm{h}$ above background for indoor areas (Table 1).

\section{Airborne Radon Concentrations}

The results for ${ }^{222} \mathrm{Rn}$ decay products, converted to number of working levels (WL), show concentrations of 0.0075 and $0.0085 \mathrm{WL}$ for the north and south sides of the basement, respectively, and $0.0016 \mathrm{WL}$ for the den. These values are well below the DOE guideline of $0.02 \mathrm{WL}$

\section{Outdoor Survey Results}

\section{Gamma Radiation Levek}

Gamma radiation levels measured during a scan of the surface of the property were 10) to $15 \mu \mathrm{R} / \mathrm{h}$ in the front yard with the exception of $20 \mu \mathrm{R} / \mathrm{h}$ at the brick surface on the north corner of the house itself. Exposure rates in the backyard were gencrally 10 to 25 $\mu R / h$. One small area near the flower bed in the soulhwest corner of the lot (approximately $0.8 \mathrm{~m}^{2}$ ) read $59 \mu \mathrm{R} / \mathrm{h}$. At that location, the gamma measurement was 
$35 \mu \mathrm{R} h$ using a lead-shielded probe. It is relevant to note that the yard haci' 'seen fertilized the previous day. Because naturally radioactive substances are frequently present in Pfertilizers, treated soil typically exhibits elevated gamma exposure rates. Readings at the rear property line near the railroad tracks changed from 25 to $30 \mu \mathrm{R} / \mathrm{h}$ when an unshielded

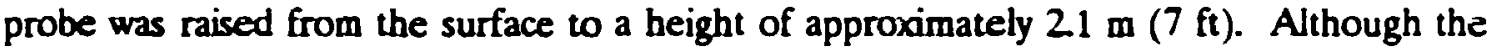
Maywood Interim Storage Site pile was not in direct line of sight at this location, it was evident that the elevated gamma was emanating from that source. Under certain conditions, extraneous radiation ("shine") emanating from a source extrinsic to the area of concern will confound measurements in that area. The source of the scattered radiation at this site is the large, heavily contaminated storage pile.

\section{Systematic and Biased Soil Samples}

Two systematic (S) and seven biased (B) soil samples -vere taken from five different locations on the property for radionuclide analyses. Sampling locations are shown in Fig. 2. with results of laboratory analyses provided in Table 3. Concentrations of radium and thorium in the systematic samples were 1.3 and $0.7 \mathrm{pCi} / \mathrm{g}$ and 1.7 and $1.0 \mathrm{pCi} / \mathrm{g}$, respectively.

Radium-226 and ${ }^{232} \mathrm{Th}$ concentrations in biased samples ranged from 0.90 to $2.8 \mathrm{pCi} / \mathrm{g}$ and 1.3 to $31 \mathrm{pCi} / \mathrm{g}$, respectively. The ${ }^{232} \mathrm{Th}$ concentrations found at sample location $\mathrm{B} 1$ are well above those normally found in coal ash and may be due to $\mathrm{MCW}$ residues. Because the area having the maximum ${ }^{232} \mathrm{Th}$ concentration $(31 \mathrm{pCi} / \mathrm{g}$ in sample B1A) is $<1 \mathrm{~m}^{2}$, the DOE "hot spot" criterion of $50 \mathrm{pCi} / \mathrm{g}$ above background for surface soil over $1 \mathrm{~m}^{2}$ or less is not exceeded (Table 1 ).

Coal ashes were visible in nearly all soil samples. Naturally occurring coai has a $\mathrm{U} / \mathrm{Ra} / \mathrm{Th}$ content. Burning the coal concentrates the natural radioactivity in the ashes, resulting in a certain amount of elevation in radionuclide content in some samples. After radiological assessment of this property and an investigation of the coal ash, all soil sampies are considered below DOE criteria.

\section{Auger Hole Soil Samples and Gamma Logging}

Auger holes were drilled ai 4 locations as indicated in Fig. 2. Varying thicknesses of subsurface soil were sampled from depths of 0 to $105 \mathrm{~cm}$ where gamma measurements indicated possible elevated concentrations of radionuclides. The results of analyses of these samples are given in Table 3 (A3A-A4C). Concentrations of ${ }^{226} \mathrm{Ra}$ and ${ }^{232} \mathrm{Th}$ in the soil samples ranged from 0.85 to 3.4 and 1.4 to $6.1 \mathrm{pCi} / \mathrm{g}$, respectively. Although scme radionuclide concentrations were higher than background, all were well below the DOE criterion (Table 1) for subsurface soil. 
Gamma logging was performed in four auger holes to characterize and further define the extent of possible contamination. The logging technique used here is not radionuclide specific. However, logging data, in conjunction with soil analyses data, may be used to estimate regions of elevated radionuclide concentrations in auger holes when compared with background levels for the area. Following a comparison of these data, it appears that any shielded scintillator readings of 1,000 rounts per minute (cpm) or greater generally indicate the presence of elevated concentrations of ${ }^{206} \mathrm{Ra}$ and/or ${ }^{232} \mathrm{Th}$. Data from the gamma profiles of the logged auger holes are graphically represented in Figs. 3 through 6.

No readings above $800 \mathrm{cpm}$ were detected in holes 1 and 2 Readings at depths between 30 and $\left.1 \mathrm{C}^{\prime}\right) \mathrm{cm}$ were greater than $1,000 \mathrm{cpm}$ in auget hole 3 , with a maximum reading of $1,400 \mathrm{cpm}$ at $61 \mathrm{~cm}$. Elevated readings were between 61 and $76 \mathrm{~cm}$ in hole 4 with a maximum of $1,800 \mathrm{cpm}$ at $61 \mathrm{~cm}$. The areas of highest gamma reading generally correspond to the greatest concentrations of radionuclides shown in Table 3. Apparent coal ashes viere observed in each location coincident with an elevated reading. The analysis results are consistent with other samples containing ash that have been collected in the Maywood/Lodi area. The slight elevation in radionuclide concentration in the coal ash is due to the naturally occurring radioactive elements in coal.

\section{SIGNIFICANCE OF FINDINGS}

Measurements taken at 146 West Central Avenue indicated that the property contains a small amount of residual radioactivity outooors. Some values were greater than background levels typically encountered in the nortiern New Jersey area. Nevertheless, the survey demonstrates that no radiation levels nor radionuclide concentrations exceed the applicable DOE criteria. The property survey and an investigation of coal ash found in soil samples reveals, with one exception, that the source of the slight elevations may be attributed to several factors unrelated to former processing operations at the MCIN. These include recent fertilization of the lawn and flower beds, and natura!ly radioactive coal ashes in the soil. In addition, radiation emanating from the nearby storage sile made it difficult to discern the degree of contamination on the south end of the property. Furthermore, the contaminated railroad property will undergo remedial action at sume time in the future. Therefore, although results show that no remedial action is needed on the property, the application of the ALARA (As Low As Reasonably Achievable) policy may justify coricurrent remoyal of this contiguous contamination from the south end of 146 West Central Avenue. 


\section{REFERENCES}

1. W. D. Cottrell, ORNL, to A J. Whitman, DOE/HQ, correspondence, "Radiological Survey of Private Properties in Lodi, New Jersey" (August 15, 1984).

2. T. E. Myrick, B. A. Berven, W. D. Cottrell, W. A. Goldsmith, and F. F. Haywood, Procedures Manual for the ORNL Radiological Survey Activities (RASA) Program, Oak Ridge National Laboratory ORNL/TM-8600 (April 1987).

3. U. S. Department of Energy, Guidelines jor Residual Radioactivity at Formerly Utilized Sites, Remedial Action Program and Remote Surplus Facilities Management Program Sites (Rev. 2 March 1987).

4. E. G. Delaney, DOE/HQ, to S. Ahrends, ORO, correspondence, "Revised Hot Spot Guidelines for FUSKAP and Remote SFMP Sites" (December 1, 1986).

5. T. E Myrick and B. A Berven, State Background Radiation Levels: Results of Measurements Taken During 1975-1979, Oak Ridge National Laboratory. ORNL/TM-7343 (November 1981).

6. U.S. Depattment of Energy, Radiological Survey of the Middlesex Municipal Landfill, Middlesex, New Jersey DOE/EV-0005/20 (Aprí1 1980). 


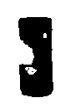
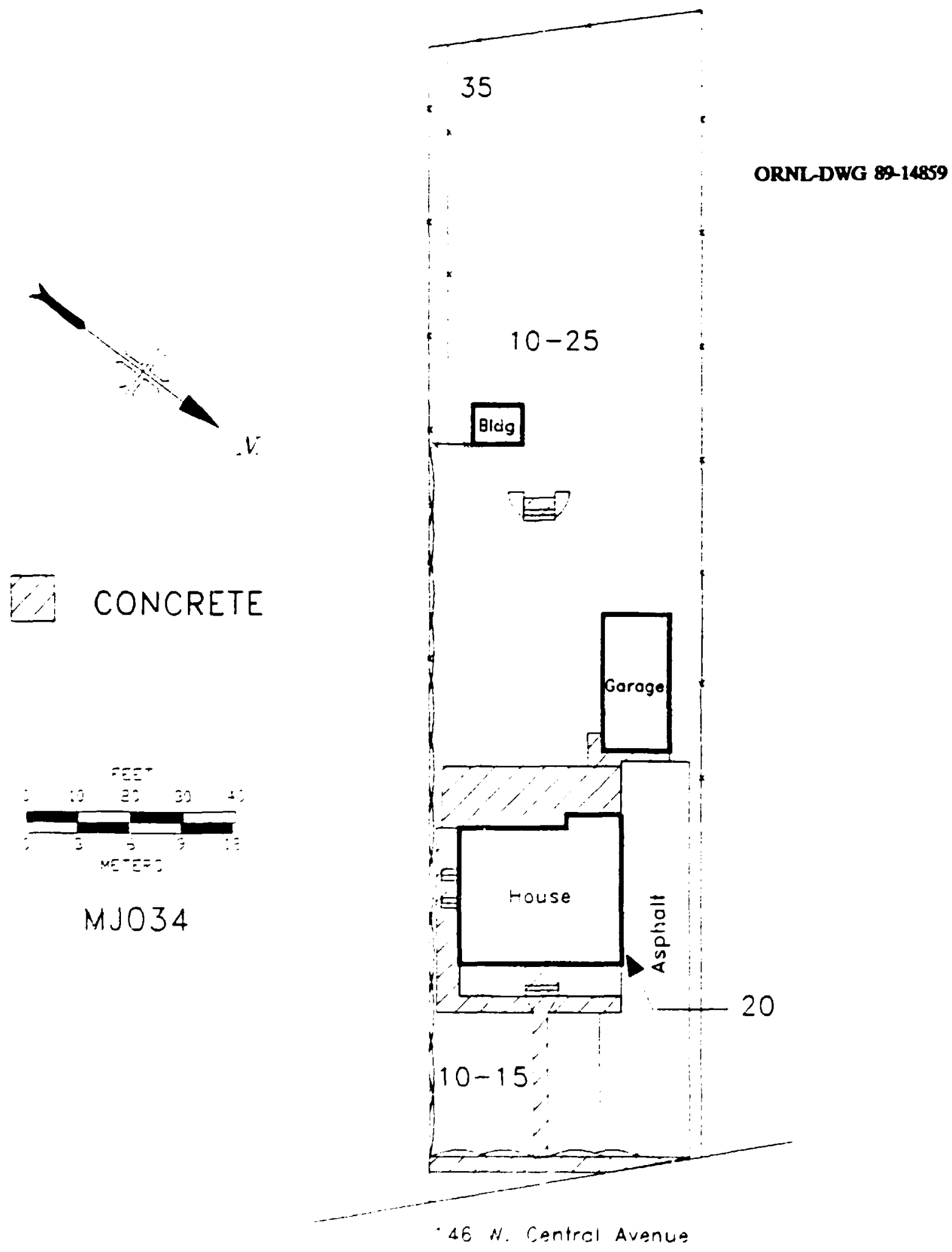

$\mathrm{MJO34}$

Fig. 1. Gamma radiation levels $(\mu \mathrm{R} / \mathrm{h})$ measured on the surface outdoors at 146 West Central Avenue, Mavwood, New Jersey (MJ034). 

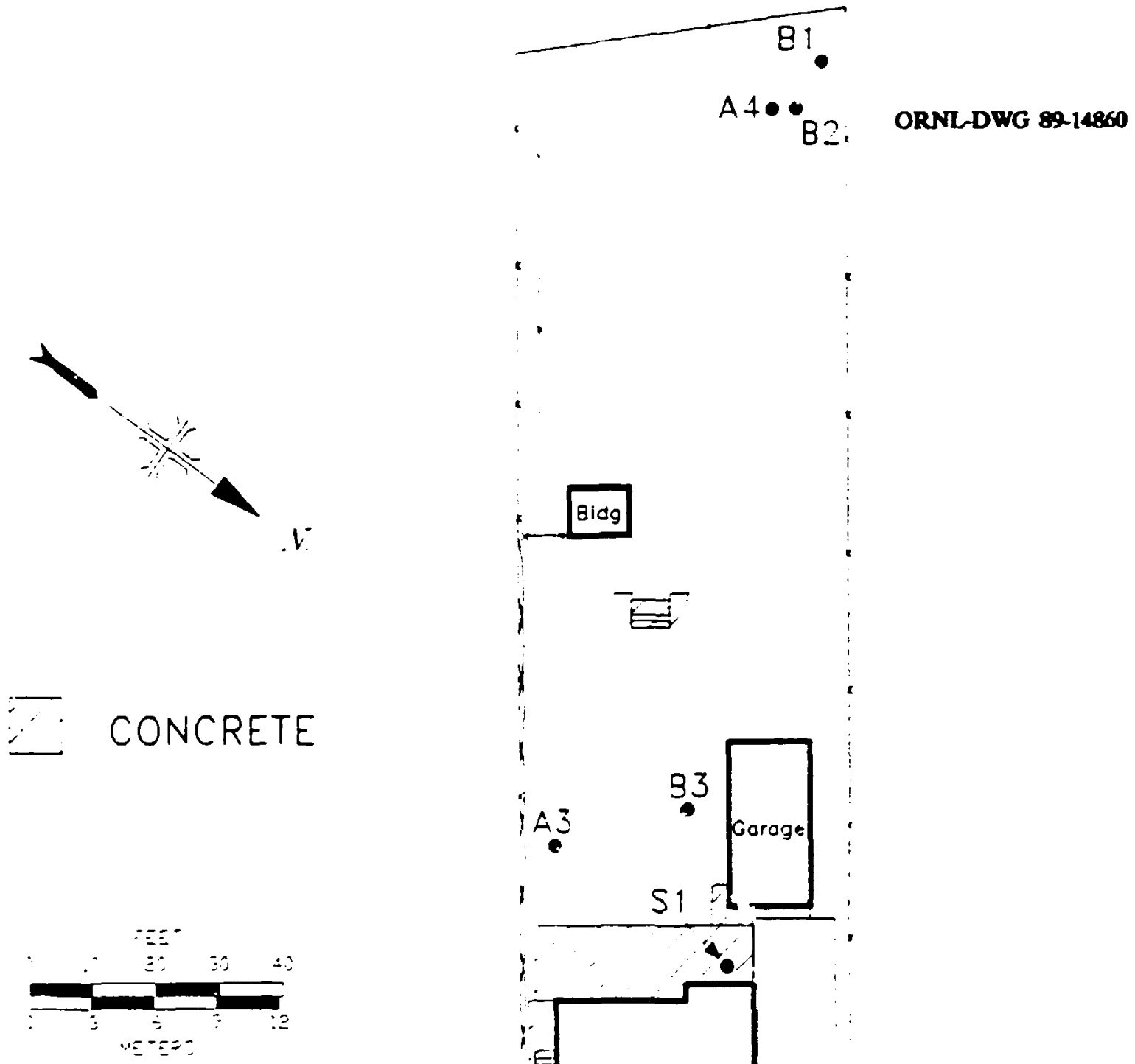

$\mathrm{MJO34}$

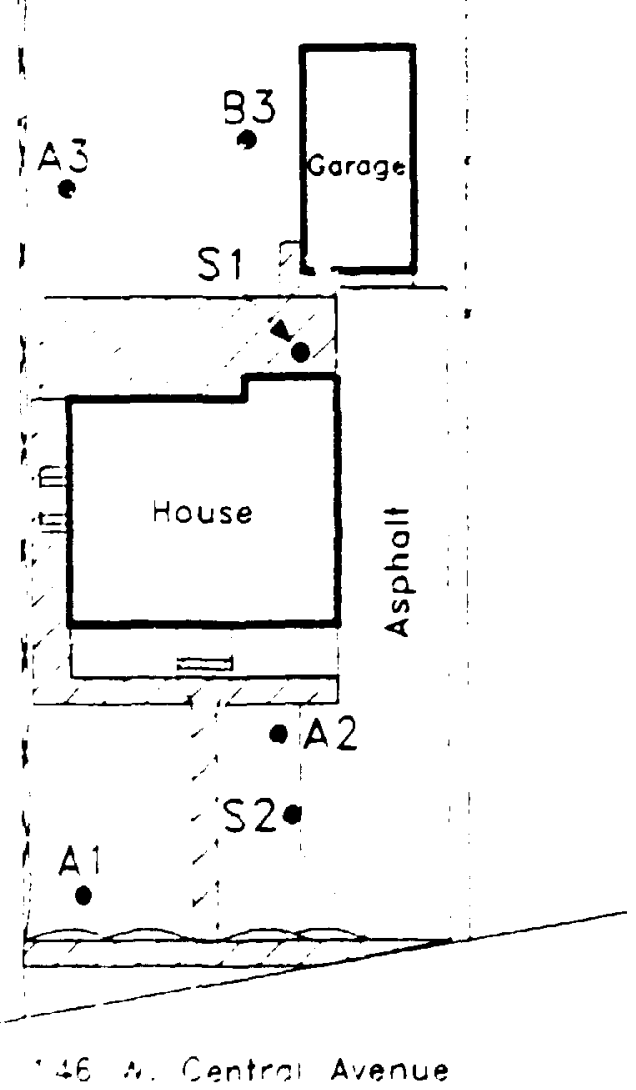

Fig. 2 Diagram showing locations of soil samples taken at 146 West Central Avenue, Maywoud, New Jersey (MJ034). 
ORNL-DWG 89-14861

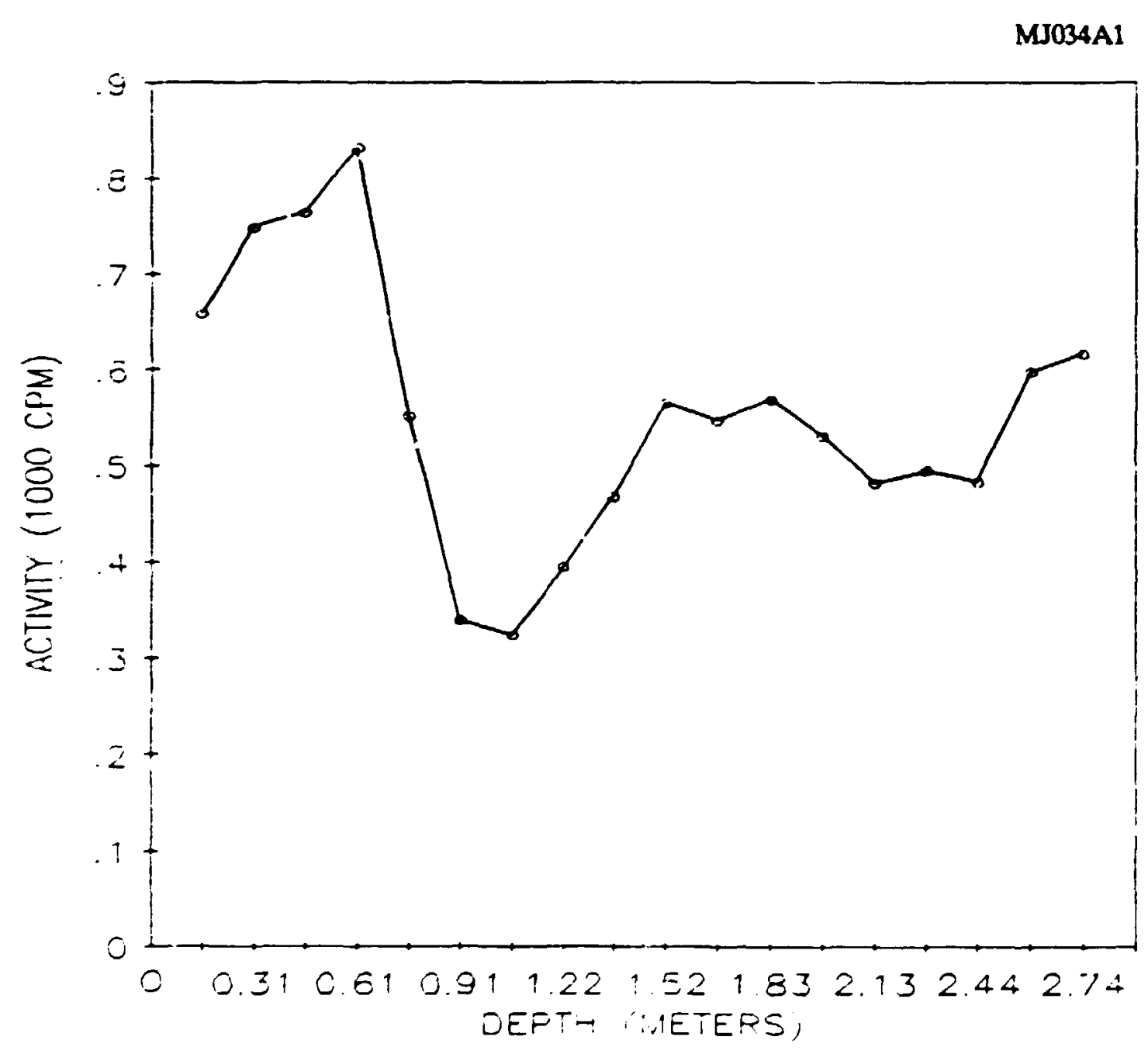

Fig. 3. Gamma profile of auger hole 1 at 146 West Central Avenue, Maywood, New Jersey. 
ORNL-DWG 89-14862

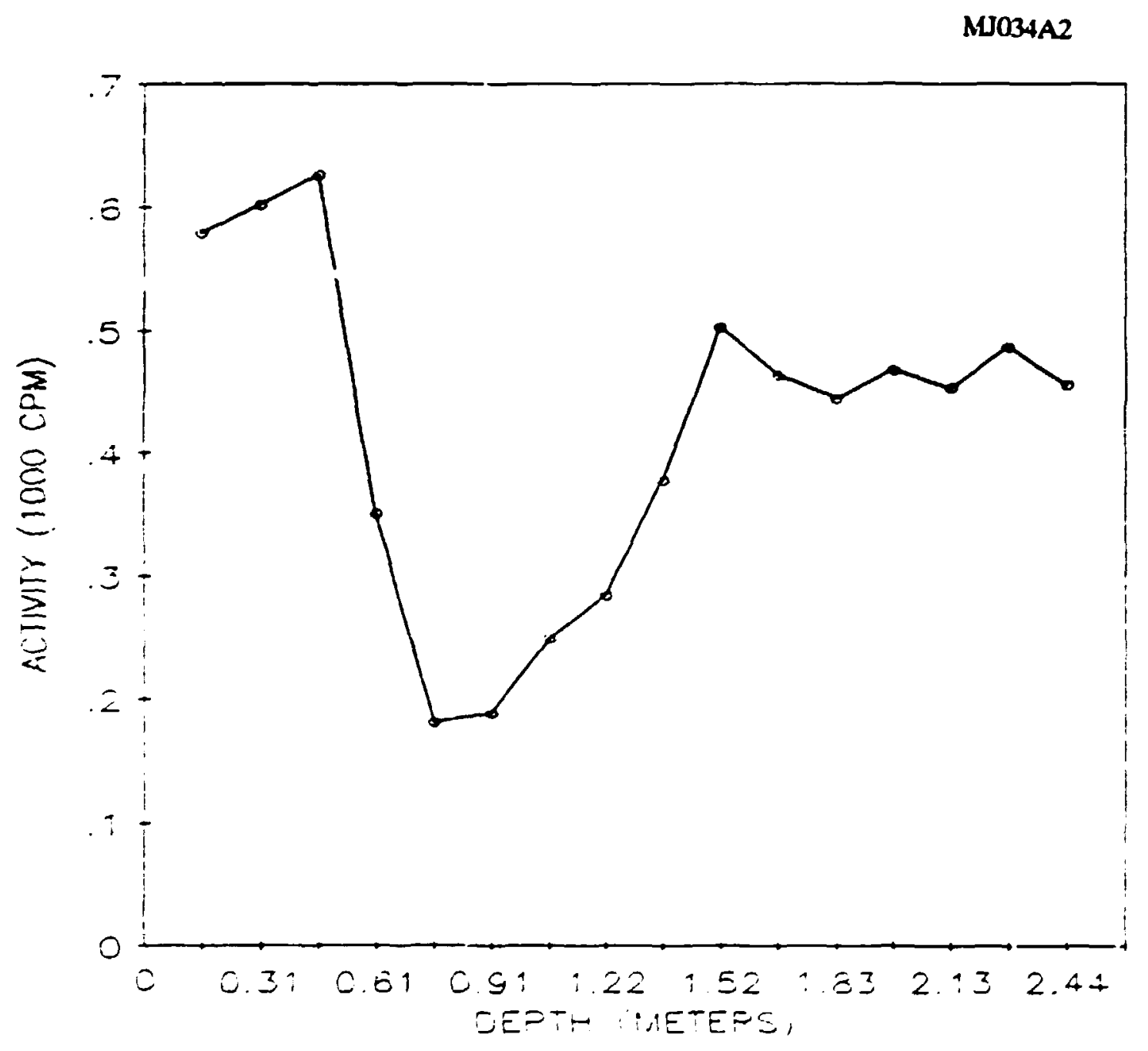

Fig. 4. Gamma profile of auger hole 2 at 146 West Central Avenue, Maywood, New Jersey. 
ORNL-DWG 89-14863

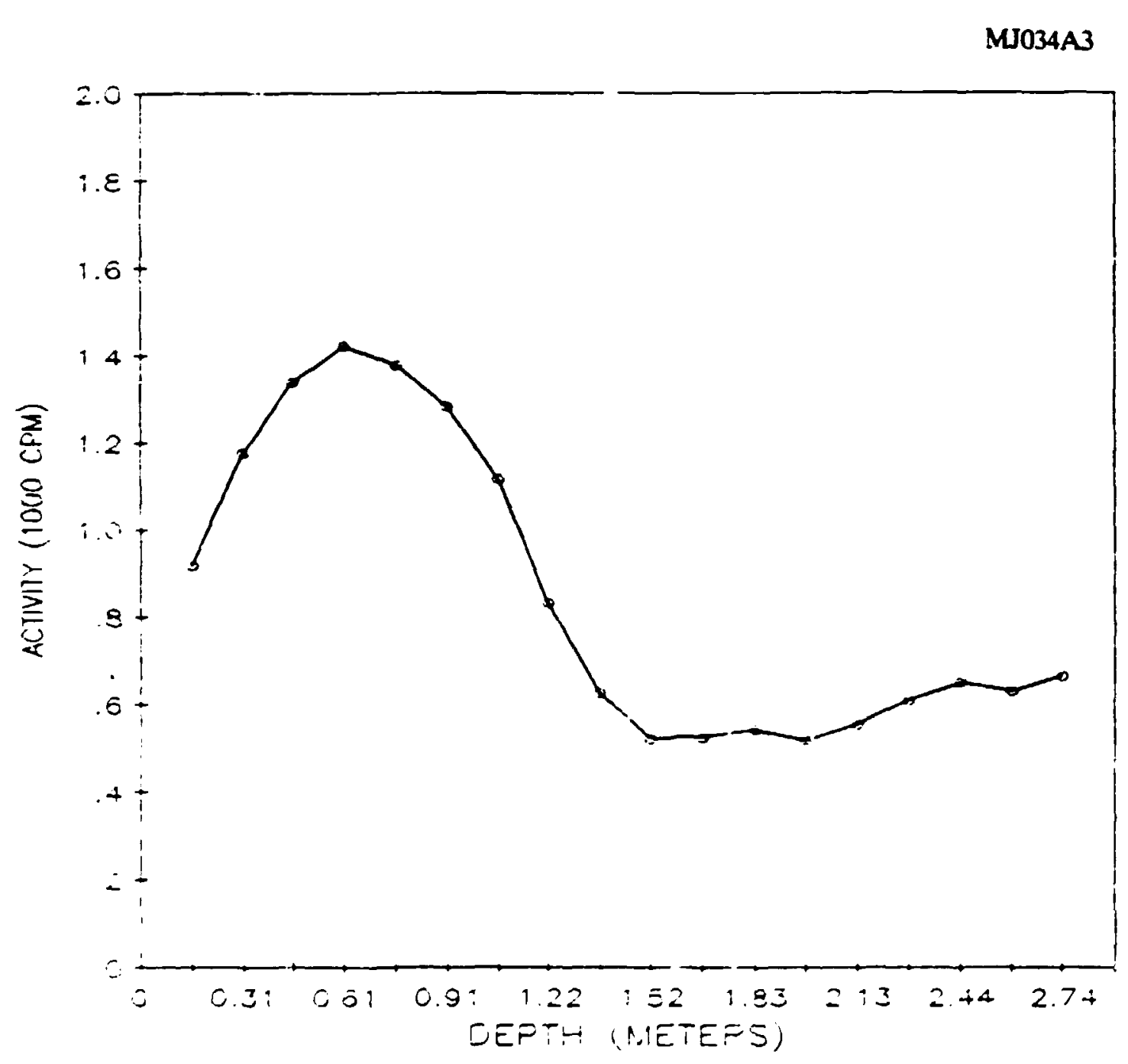

Fig. 5. Gamma profile of auger hole 3 at 146 West Central Avenue, Maywood, New Jersey. 
ORNL-DWG 89-14864

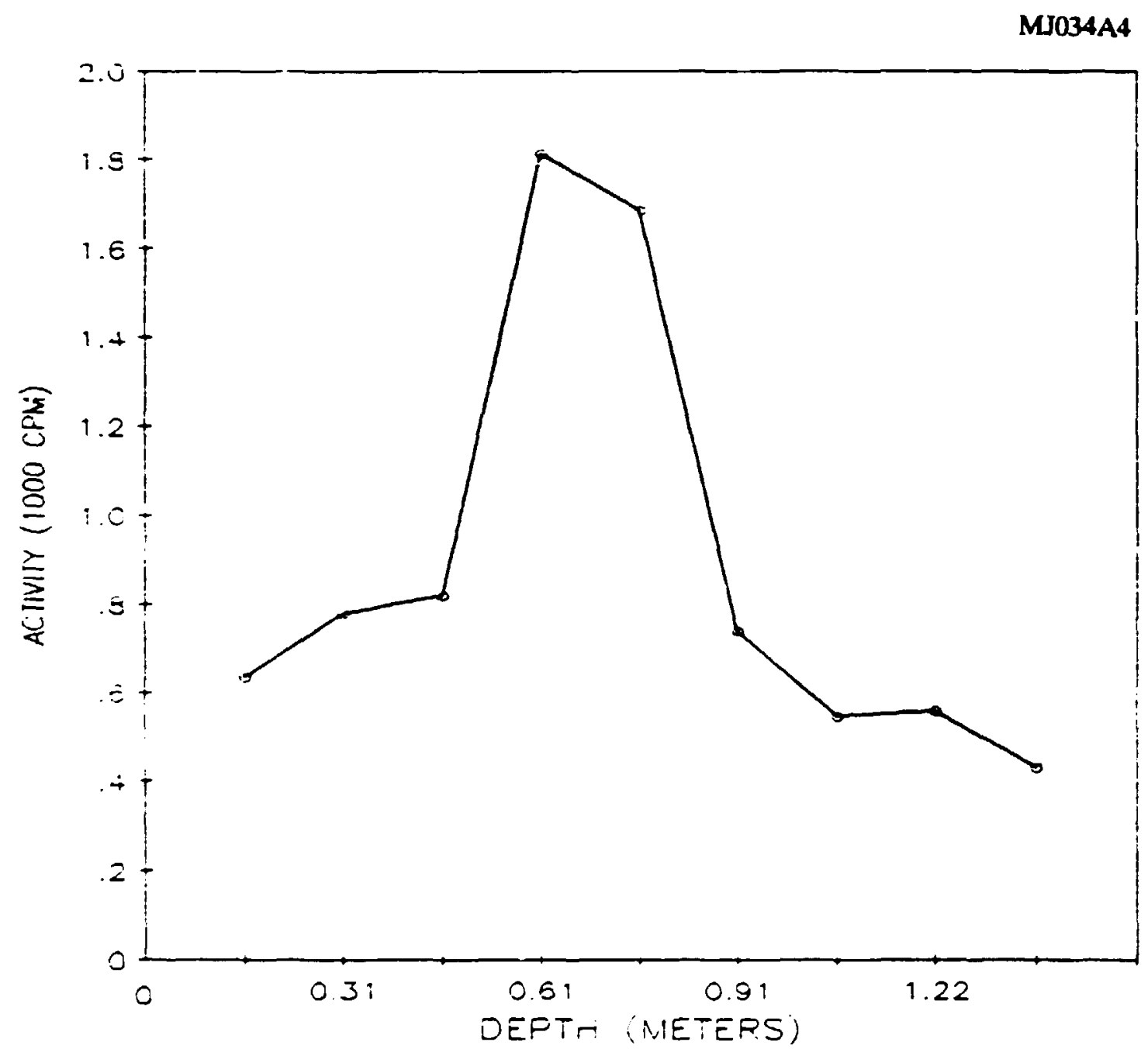

Fig. 6. Gamma profile of auger hole 4 at 146 West Central Avenue, Maywood, New Jersey. 
Table 1. Applicable guidelines for protection against radiatione

\begin{tabular}{|c|c|c|}
\hline Mode of exposure & Exposure conditions & Guideline value \\
\hline Gamma radiation & $\begin{array}{l}\text { Indoor gamma radiation level } \\
\text { (above background) }\end{array}$ & $20 \mu R / h$ \\
\hline $\begin{array}{l}\text { Exposure to } \\
\text { progeny }\end{array}$ & $\begin{array}{l}\text { Average annual radon progeny } \\
\text { concentration (including back- } \\
\text { ground) }\end{array}$ & $0.02 \mathrm{WL}$ \\
\hline $\begin{array}{l}\text { Radionuclide concen- } \\
\text { trations in soil }\end{array}$ & $\begin{array}{l}\text { Maximum permissible concentra- } \\
\text { iration of the following radionuc- } \\
\text { lides in soil above background } \\
\text { over a } 100 \mathrm{~m}^{2} \text { area } \\
\qquad \begin{array}{c}232 \mathrm{Th} \\
230 \mathrm{Th} \\
228 \mathrm{Ra} \\
{ }^{226} \mathrm{Ra}\end{array}\end{array}$ & $\begin{array}{l}5 \mathrm{pCi} / \mathrm{g} \text { averaged over the } \\
\text { first } 15 \mathrm{~cm} \text { of soil below the } \\
\text { surface; } 15 \mathrm{pCi} / \mathrm{g} \text { when av- } \\
\text { eraged over } 15-\mathrm{cm} \text { soil lay- } \\
\text { ers more than } 15 \mathrm{~cm} \text { below } \\
\text { the surface }\end{array}$ \\
\hline $\begin{array}{l}\text { Guidelines for non- } \\
\text { homogeneous contam- } \\
\text { ination (used in addi- } \\
\text { tion to the } 100 \mathrm{~m}^{2} \\
\text { guideline) }\end{array}$ & $\begin{array}{l}\text { Applicable to locations meeting } \\
\text { the above criterion but } \leq 25 \mathrm{~m}^{2} \\
\text { with significantly elevated con- } \\
\text { centrations of radionuclides }\end{array}$ & $\begin{array}{l}\text { Concentration limits for ap- } \\
\text { plication to "hot spots" } \\
\text { varying in size as follows: } \\
\begin{array}{cc}\left(\mathrm{m}^{2}\right) & (\mathrm{pCi} / \mathrm{g}) \\
<1 & 50 \\
1-<3 & 30 \\
3-<10 & 15 \\
10-25 & 10\end{array}\end{array}$ \\
\hline
\end{tabular}

${ }^{a}$ From Reference 3.

${ }^{b}$ These guideline values are applicable to surface concentrations of ${ }^{232} \mathrm{Th},{ }^{230} \mathrm{Th},{ }^{228} \mathrm{Ra}$, and ${ }^{206} \mathrm{Ka}$ only; for other radionuclides and subsurface values, see Reference 3.

c."Every reasonable effort shall be made to identify and remove any source which has a concentration exceeding 30 times the guideline value, irrespective of area." See Reference 4. 
Table 2. Background radiation levels for the northern New Jersey area

\begin{tabular}{cc}
$\begin{array}{c}\text { Type of radiction measurement } \\
\text { or sample }\end{array}$ & $\begin{array}{c}\text { Radiation level or } \\
\text { radionuclide concentration }\end{array}$ \\
\hline $\begin{array}{cc}\text { Gamma exposure rate at } 1 \mathrm{~m} \\
\text { above ground surface }(\mu \mathrm{R} / \mathrm{h})^{a}\end{array}$ & 8 \\
Concentration of radionuclides & \\
in soil (pCi/g) & \\
$226 \mathrm{Ra}$ & 0.9 \\
$232 \mathrm{Th}$ & 0.9 \\
$238 \mathrm{U}$ & 0.9 \\
\hline
\end{tabular}

${ }^{a}$ Reference 5.

${ }^{b}$ Reference 6. 
Table 3. Coscentrations of radionuclides in soil at 146 West Central Arewee, Maywood, New Jersey (MJ034)

\begin{tabular}{|c|c|c|c|c|}
\hline \multirow{2}{*}{ Sample ${ }^{a}$} & \multirow{2}{*}{$\begin{array}{l}\text { Depth } \\
\text { (cm) }\end{array}$} & \multicolumn{3}{|c|}{ Radionuclide concentration $(\mathrm{pCi} / \mathrm{g}$ ) } \\
\hline & & ${ }^{226} \mathrm{Ra}^{b}$ & ${ }^{232} \mathrm{Th}^{6}$ & ${ }^{238} U^{b}$ \\
\hline \multicolumn{5}{|c|}{ Systemotic samples } \\
\hline S1 & $0-15$ & $1.3 \pm 0.1$ & $1.7 \pm 0.1$ & $c$ \\
\hline S2 & $0-15$ & $0.7 \pm 0.02$ & $1.0 \pm 0.04$ & $c$ \\
\hline \multicolumn{5}{|c|}{ Biased samples } \\
\hline $\mathbf{B} \mid \mathbf{A}$ & $0-15$ & $2.3 \pm 0.4$ & $31 \pm 4$ & $c$ \\
\hline BIB & $15-30$ & $1.3 \pm 0.3$ & $13 \pm 0.8$ & $c$ \\
\hline BIC & $30-40$ & $1.1 \pm 0.2$ & $7.7 \pm 1$ & $c$ \\
\hline B2A & $0-15$ & $1.2 \pm 0.2$ & $1.6 \pm 0.2$ & $c$ \\
\hline B2B & $15-30$ & $0.90 \pm 0.2$ & $1.3 \pm 0.1$ & $c$ \\
\hline B3A & $0-15$ & $2.2 \pm 0.4$ & $2.6 \pm 0.5$ & $c$ \\
\hline B3B & $15-30$ & $2.8 \pm 0.07$ & $3.0 \pm 0.4$ & $c$ \\
\hline \multicolumn{5}{|c|}{ Auger samplese } \\
\hline A3A & $45-60$ & $2.7 \pm 0.1$ & $3.1 \pm 0.09$ & $3.9 \pm 0.3$ \\
\hline A3B & $60-75$ & $3.4 \pm 0.1$ & $3.6 \pm 0.4$ & $8.8 \pm 8$ \\
\hline A3C & $75-90$ & $2.8 \pm 0.01$ & $2.8 \pm 0.02$ & $3.3=0.3$ \\
\hline A3D & $90-105$ & $2.0 \pm 0.04$ & $2.2 \pm 0.07$ & $3.7 \pm 1$ \\
\hline A4A & $45-60$ & $0.85 \pm 0.02$ & $1.4 \pm 0.03$ & $<2.1$ \\
\hline A4B & $60-75$ & $1.1 \pm 0.2$ & $6.1 \pm 0.1$ & $20 \pm 3$ \\
\hline$A+C$ & $75-90$ & $1.2 \pm 0.04$ & $1.6 \pm 0.07$ & $33 \pm 2$ \\
\hline
\end{tabular}

${ }^{a}$ Locations o: soil samples are shown on Fig. 2.

${ }^{b}$ Indicated counting error is at the $95 \%$ confidence level $( \pm 2 \sigma)$.

${ }^{c}$ These samples were not analyzed for ${ }^{238} \mathrm{U}$.

${ }^{d}$ Biased samples are taken from areas shown to have elevated gamma exposure rates.

'Auger samples are those taken from holes drilled to further define the depth and extent of radioactive material. Holes are drilled where the surface may or may not be contaminated. 